\title{
Impact of increased temperatures on the geochemical behaviour of trivalent actinides in aquatic systems
}

\author{
Andrej Skerencak-Frech ${ }^{1}$, Petra Panak ${ }^{2}$, Kathy Dardenne ${ }^{1}$, Jörg Rothe $^{1}$, Xavier Gaona ${ }^{1}$, \\ Marcus Altmaier ${ }^{1}$, and Horst Geckeis ${ }^{1}$ \\ ${ }^{1}$ Institut für Nukleare Entsorgung - INE, Karlsruher Institut für Technologie - KIT, Karlsruhe, 76021, Germany \\ ${ }^{2}$ Physikalisch-Chemisches Institut - PCI, Heidelberg University, Heidelberg, 69120, Germany \\ Correspondence: Andrej Skerencak-Frech (andrej.skerencak@kit.edu)
}

Published: 10 November 2021

\begin{abstract}
The Safety Case for a radioactive waste repository in deep geological formations requires detailed chemical and thermodynamic information on the stored radionuclides in their relevant oxidation states. Although a comprehensive summary of critically evaluated thermodynamic data is available via the blue book series of the NEA-TDB ("Nuclear Energy Agency - Thermochemical Database"), the majority of this data is limited to ambient conditions (Grenthe et al., 2020). In the case of the disposal of high-active, heat-producing waste, however, the near-field of the repository will experience increased temperatures at early operative phases for several hundred or a few thousand years. Radionuclides may come into contact with aquatic solutions or brines at elevated temperatures in the case of early canister failure. Besides other factors of the overall disposal concept (e.g. the geometry of the repository, type and amount of stored radionuclide inventories), host rock characteristics themselves limit the extent of the allowable temperature increase. For example, in clay formations the maximum temperature should stay at around or below $\sim 100^{\circ} \mathrm{C}$ in order to avoid an irreversible change in the host rock retention capacity, whereas rock salt allows much higher temperatures of up to $200^{\circ} \mathrm{C}$.

Increased temperatures will have a distinct impact on the geochemical behaviour of radionuclides, potentially affecting their mobility and retention in the near field. Besides reactions at the solid-liquid interface (e.g. dissolution/precipitation reactions of the waste matrix, sorption reactions of the radionuclides to surfaces), complexation reactions with inorganic and organic ligands present in the aqueous phase potentially affect migration behaviour of the radionuclides. A quantitative thermodynamic description of these processes requires standard stability constants $\left(\log \beta_{n}^{0}(T)\right)$, as well as standard reaction enthalpies and entropies $\left(\Delta_{\mathrm{r}} H_{m, n}^{0}, \Delta_{\mathrm{r}} S_{m, n}^{0}\right)$. The precise experimental determination of these data for all relevant radionuclide/ligand reactions requires a vast amount of time and effort. In this regard, reliable extrapolation methods in particular for standard stability constants valid for $25^{\circ} \mathrm{C}$ to higher temperatures are considered to support a comprehensive description. Recently, the German Federal Ministry of Education and Research (BMBF)-funded collaborative research project "Therm AC" focused on the experimental determination of new thermodynamic data at higher temperatures, as well as the comparison with the analogous results yielded by extrapolation methods. The Thermochemical Database Project of the OECD-NEA (NEA-TDB) is currently in the process of preparing a comprehensive state-of-the-art report on the high temperature thermodynamics of radionuclides, further emphasizing the particular relevance of this interesting topic.

Within this contribution, a critical overview on the recent advances in the field of high temperature studies of radionuclides in aqueous solutions will be given. Besides summarizing information on key technical aspects relevant for high temperature studies, the effect of increased temperatures on the complexation of trivalent actinides with chloride will be discussed in more detail in order to illustrate newly derived in-depth understanding of the impact of increased temperatures on the (geo)chemical behaviour of trivalent actinides on the molecular scale (Skerencak-Frech et al., 2014).
\end{abstract}

Kurzfassung. Der Sicherheitsnachweis für ein Endlager für radioaktive Abfälle in tiefen geologischen Formationen erfordert detaillierte chemische und thermodynamische Informationen über die gelagerten Radionuk- 
lide in ihren relevanten Oxidationsstufen. Zwar ist über die Bluebook-Reihe der NEA-TDB („Nuclear Energy Agency - Thermochemical Database") eine umfassende Zusammenfassung kritisch bewerteter thermodynamischer Daten verfügbar, allerdings beschränkt sich der Großteil davon auf Umgebungsbedingungen (Grenthe et al., 2020). Bei der Entsorgung hochaktiver, wärmeerzeugender Abfälle jedoch wird das nähere Umfeld des Endlagers in frühen Betriebsphasen für mehrere hundert oder einige tausend Jahre erhöhten Temperaturen ausgesetzt sein, bei welchen Radionuklide im Falle einer frühen Beschädigung des Kanisters mit wässrigen Lösungen oder Solen in Kontakt kommen können. Neben anderen Faktoren des Endlagerkonzepts (z. B. Geometrie des Endlagers, Art und Menge der gespeicherten Radionuklide) begrenzen die Wirtsgesteinseigenschaften selbst das Ausmaß der zulässigen Temperaturerhöhung. So sollte beispielsweise in Tonformationen die Maximaltemperatur um oder unter $\sim 100^{\circ} \mathrm{C}$ bleiben, um eine irreversible Änderung des Wirtsgesteinsrückhaltevermögens zu vermeiden, während Steinsalz deutlich höhere Temperaturen von bis zu $200^{\circ} \mathrm{C}$ zulässt.

Erhöhte Temperaturen werden das geochemische Verhalten von Radionukliden deutlich beeinflussen und möglicherweise ihre Mobilität und das Rückhaltevermögen im näheren Umfeld beeinträchtigen. Neben Reaktionen an der Grenzfläche zwischen festen und flüssigen Phasen (z. B. Lösungs-/Fällungsreaktionen der Abfallgrundsubstanz, Sorptionsreaktionen der Radionuklide an Oberflächen) beeinflussen eventuell auch komplexbildende Reaktionen mit in der wässrigen Phase vorhandenen organischen und anorganischen Liganden das Migrationsverhalten der Radionuklide. Eine quantitative thermodynamische Beschreibung dieser Prozesse erfordert sowohl Standardstabilitätskonstanten $\left(\log \beta_{n}^{0}(T)\right)$ als auch Standardreaktionsenthalpien und -entropien $\left(\Delta_{\mathrm{r}} H_{m, n}^{0}, \Delta_{\mathrm{r}} S_{m, n}^{0}\right)$. Die genaue experimentelle Ermittlung dieser Daten für alle relevanten RadionuklidLiganden-Reaktionen ist äußerst arbeits- und zeitaufwendig. In diesem Kontext werden zuverlässige Extrapolationsmethoden insbesondere für Standardstabilitätskonstanten, die für $25^{\circ} \mathrm{C}$ bis zu höheren Temperaturen valide sind, als Grundlage für eine umfassende Beschreibung angesehen. In letzter Zeit konzentrierte sich das vom deutschen BMBF (Bundesministerium für Bildung, Wissenschaft und Forschung) geförderte Forschungsverbundprojekt „ThermAC“ auf die experimentelle Ermittlung neuer thermodynamischer Daten bei höheren Temperaturen und den Vergleich mit den entsprechenden Ergebnissen der Extrapolationsmethoden. Das thermochemische Datenbankprojekt der OECD-NEA (NEA-TDB [OECD: „Organisation for Economic Co-operation and Development"]) ist derzeit damit befasst, einen umfassenden State-of-the-Art-Bericht zur Hochtemperaturthermodynamik von Radionukliden zu erstellen, womit die besondere Relevanz dieses interessanten Themas weiter unterstrichen wird.

In diesem Beitrag wird ein kritischer Überblick über die jüngsten Fortschritte im Bereich der Hochtemperaturstudien von Radionukliden in wässrigen Lösungen gegeben. Neben der Zusammenfassung der für Hochtemperaturuntersuchungen relevanten technischen Schlüsselaspekte wird der Einfluss erhöhter Temperaturen auf komplexbildende Reaktionen zwischen trivalenten Aktinoiden und Chlorid näher beleuchtet, um ein neu gewonnenes umfassenderes Verständnis des Einflusses erhöhter Temperaturen auf das (geo-)chemische Verhalten trivalenter Aktinoide auf molekularer Ebene zu veranschaulichen (Skerencak-Frech et al., 2014).

\section{References}

Grenthe, I., Gaona, X., Plyasunov, A. V., Linfeng, R., Runde, W. H., Grambow, B., Konings, R. J., Smith, A. L., and Moore, E. E.: Second Update on the chemical Thermodynamics of Uranium, Neptunium, Plutonium, Americium and Technetium, vol 14, OECD Publications, Paris, France, 2020.
Skerencak-Frech, A., Fröhlich, D. R., Rothe, J., Dardenne, K., and Panak, P. J.: Combined Time-Resolved Laser Fluorescence Spectroscopy and Extended X-ray Absorption Fine Structure Spectroscopy Study on the Complexation of Trivalent Actinides with Chloride at $T=25-200{ }^{\circ} \mathrm{C}$, Inorg. Chem., 53, 1062-1069, https://doi.org/10.1021/ic4025603, 2014. 